\title{
Editorial
}

\section{Letter from Editor}

2015년 4월에 발행되는 Journal of Clinical Nutrition (JCN) 에는 모두 3 편의 종설과 2 편의 원저를 게재하였습니다.

한림대학교 동탄성심병원의 신동우 교수가 기고한 “영양집중 지원팀의 집중영양치료료, 무엇이 문제이고 어떻게 대처해야 하는가?”는 국내 영양집중지원팀의 집중영양치료 현황과 그 문 제점에 대해 심도 깊게 다룬 의미 있는 보고서입니다. ${ }^{1} 2014$ 년 8 월 국내에서 “집중영양치료료”가 의료 수가로 인정되면서 각 병원에서 활동 중인 영양집중지원팀의 활동에 급여화가 이루어 졌습니다. 입원 환자들의 영양관리에 대한 질 향상이 이루어지 긴 했지만, 이와 함께 나타날 수 있는 많은 문제점들을 잘 정리 하였습니다.

아주대학교병원의 이연희 영양사와 이재명 교수는 중환자 영 양 치료를 위한 생체전기저항분석법의 활용에 대한 종설을 기 고하였습니다. ${ }^{2}$ 중환자에서 흔히 발생하는 체액불균형과 근육 손실 그리고 체단백감소들을 측정하기 위한 다양한 방법들이 제기되어 왔으나, 대부분의 방법들은 환자들의 영양상태를 정 확히 파악하는 데 한계를 갖고 있었습니다. "생체전기저항분석 법”은 침습적이지 않으면서도 환자들의 체지방량, 근육량을 부 위별로 제공할 수 있는 방법으로 금번 종설에서 다양한 임상결 과들을 소개하고 있습니다.

중앙대학교병원의 김정욱 교수가 보고한 영양재개증후군에 대한 종설은 영양 부족이나 영양실조 환자들에 대한 영양공급 시 발생할 수 있는 영양재개증후군의 원인과 진단 그리고 치료 에 대한 내용을 담고 있습니다. ${ }^{3}$ 영양 결핍 환자에 대한 영양 공 급을 담당하고 있는 의료진의 입장에서 반드시 고려해야 할 합 병증으로, 본 종설은 많은 도움을 줄 수 있을 것으로 생각됩니 다.

이번 호에 게재된 두 편의 원저는 모두 실제 영양환자에 대한 영양 지원 임상경험을 바탕으로 한 결과를 정리한 내용을 담고 있습니다. ${ }^{4}$ 세브란스병원 김윤정, 백영미 간호사, 김경식 교수 등이 보고한 “외과병동환자 영양관리실태”는 경장 영양 공급을
시행받은 외과 환자들의 임상 결과를 정리한 논문입니다. 경장 영양 공급시의 구체적인 방법과 발생할 수 있는 합병증 등을 잘 정리함으로써 이를 시행하는 회원들에게 좋은 경험을 전달할 수 있을 것으로 생각됩니다.

세브란스병원 황희숙 영양사, 이재길 교수 등이 보고한 “중환 자실 환자의 영양상태에 대한 영양 협진 적용 효과”는 중환자실 환자 영양 지원 현황에 대한 보고와 영양 협진 여부에 따른 영양 공급량과 영양 상태에 대한 정리한 원저입니다. 본 연구를 통해 중환자실 환자들의 영양 협진의 중요성을 강조하고 있습니다.

저희 JCN은 2014년 4월 현재 명칭의 저널로 개편 후 많은 관심 과 성원 속에 발전을 거듭하고 있습니다. 최근 유럽정맥경장영양 학회(European Society Parenteral Enteral Nutrition)로부터 공식학회지 중의 하나인 Clinical Nutrition ESPEN의 Section Associate Editor로 참여해 줄 것을 요청 받아, 제가 $\mathrm{JCN}$ 의 편집 위원장 자격으로 참여하게 되었습니다. 저희 학회지의 위상을 높 일 수 있는 계기가 될 것으로 생각됩니다. 하지만, 대내적으로는 최근 투고 논문 편수가 줄어들면서 일시적인 출판의 어려움을 겪 고 있습니다. 한국정맥경장영양학회 회원으로서 학회의 공식 학 회지인 JCN에 보다 실질적인 공헌을 부탁드리는 바입니다.

\section{REFERENCES}

1. Shin D. Reimbursement of nutritional support team, what is the problem and how can we manage it? J Clin Nutr 2015;7(1):2-8.

2. Lee YH, Lee JM. Use of bioelectrical impedance analysis for nutritional treatment in critically ill patients. J Clin Nutr 2015; 7(1):9-14.

3. Kim JW. Refeeding syndrome. J Clin Nutr 2015;7(1):15-22.

4. Kim YJ, Baek YM, Kim SY, Moon MR, Park KH, Paeck SH, et al. The current status of enteral feeding management in general surgical ward. J Clin Nutr 2015;7(1):23-7.

5. Hwang HS, Lee SH, Lee H, Kim KS, Chung SJ, Lee JG. Effects of nutrition consultation on nutritional status in critically ill surgical patients. J Clin Nutr 2015;7(1):28-34. 